\title{
The load-bearing capacity of hanging piles by the strength criterion of a pile or soil material
}

\author{
Несущая способность висячих свай \\ по критерию прочности материала сваи или грунта
}

\author{
T.V. Ivanova, \\ I.U. Albert, \\ B.D. Kaufman, \\ S.G. Shulman, \\ JSC "B.E. Vedeneev VNIIG", St. Petersburg, \\ Russia
}

Key words: pile foundation; load-bearing capacity; probability theory; possibility theory; the combined methods of reliability assessment; buildings; construction; civil engineering

\author{
Канд. техн. наук, ученый секретарь \\ T.В. Иванова, \\ д-р техн. наук, ведущий науч. сотрудник \\ И.У. Альберт, \\ д-р техн. наук, ведущий науч. сотрудник \\ Б.Д. Кауфман, \\ д-р техн. наук, гл. науч. сотрудник \\ С.Г. Шульман, \\ Акционерное общество "Всероссийский \\ научно-исследовательский институт \\ гидротехники имени Б.Е.Веденеева", \\ г.Санкт-Петербург, Россия
}

Ключевые слова: свайный фундамент; несущая способность; теория вероятности; теория возможности; комбинированные методы оценки надежности; сооружения; строительство; гражданское строительство

\footnotetext{
construction; civilengineering
}

Abstract. The article describes various methods of assessment of load-bearing capacity (reliability) of a pile as a main element of pile foundation. It is shown that deterministic, probabilistic and possibilistic methods have a number of advantages and limitations. An actual task is to develop new approaches to assessment of foundations load-bearing capacity. The combined method providing the optimal assessment according to the given examples is developed in the article. Some features of the proposed methods are in the probability and possibility theories application to account uncertainty or incompleteness of initial data in quantifying the reliability of a pile. Presented in the article methods for a quantitative assessment of single piles reliability can be used for more complex computational models, including multielement pile foundations and more complex models of soil foundations. These methods have not been applied to piles reliability research so far and the article pre-sented is a pioneering one and has no analogues known to the authors.

Аннотация. В статье рассмотрены различные методы оценки несущей способности (надежности) сваи как основного элемента конструкции свайного фундамента. Показано, что детерминированный, вероятностный и возможностный методы имеют ряд преимуществ и ограничений. Актуальной является задача развития новых подходов к оценке несущей способности фундаментов. В статье развит комбинированный метод, дающий оптимальную оценку, что продемонстрировано на примерах. Особенность предлагаемого метода заключена в совместном применении теорий вероятности и возможности для учета неполноты или неопределенности исходных данных при количественной оценке надежности сваи. Представленные в статье методики количественной оценки надежности одиночных свай могут быть использованы для более сложных расчетных моделей, в том числе многоэлементных свайных фундаментов и более сложных моделей грунтовых оснований.

\section{Introduction}

One of the main indicators characterizing the properties of "a pile-soil environment" system is load-bearing capacity, i.e., property of the pile to resist external load in the absence of further punching. In design practice to determine the load- bearing capacity various methods based on the use of test and experimental data are applied in the deterministic setting. Estimates of load-bearing capacity are made прочности материала сваи или грунта // Инженерно-строительный журнал. 2016. № 7(67). С. 3-12. 
using a number of empirical coefficients input into the calculations to consider the working conditions of the pile, immersion techniques, the strength characteristics of the pile material, the pile grillage structure $[1-4,9,10,15,17,22,26,29]$. Some examples of such assessments, based on the static probing results, are set out in $[27,28]$.The significant scatter of input data can dramatically affect the results obtained, which can be refined by methods described below.

An actual task is to develop new approaches to assessment of foundations load-bearing capacity. The combined method providing the optimal assessment according to the given examples is developed in the article.

Some features of the proposed methods are in the probability and possibility theories application to account uncertainty or incompleteness of initial data in quantifying the reliability of a pile.

In the works of other authors on this subject $[2-4,9,10,26]$ there is no possibility of taking into account the incompleteness and uncertainty of initial data when assessing the load-bearing capacity of a pile. In this paper this problem is solved by applying the theory of probability and possibility theory to take account of uncertainty or incompleteness of initial data in quantifying the reliability of a pile.

\section{Methods}

A condition providing the required load-bearing capacity of a pile by the method of limit states is expressed in the form of inequality:

$$
\mathrm{N}_{\mathrm{d}}<\frac{1}{k_{1}} F_{d}
$$

where $\mathrm{N}_{\mathrm{d}}$ is the axial load on the pile, $F_{d}$ - ultimate bearing capacity, $\mathrm{k}_{1}$ - safety factor.

Obviously, the result of substituting in the expression (1) known values of the axial load on the pile and ultimate bearing capacity allows us to formulate one of the two alternative, mutually exclusive judgments about the reliability of the pile. Thus the basic feature of the initial data - their random nature is ignored; both as regards the parameters of the external action and the characteristics of soil and the pile material. This can lead to the wrong conclusion on the reliability of the pile. A more reasonable estimate of reliability which takes into account the random nature of the original data and has a quantitative expression is a technique based on a probabilistic approach, possibility theory, the theory of fuzzy sets as well as their combinations [6-8, 10-14, 19-21, 23, 24].

As a simple example of the use of such methods, consider a pile reliability quantitative assessment based on the strength criteria for piles of any type and based on the bearing capacity of soil foundation in the case of a friction pile.

\section{The assessment of a pile load-bearing capacity by the strength criterion for the pile material}

In the deterministic approach the condition of providing the necessary strength of a pile material is as follows [9]:

$$
\frac{1}{\mathrm{k}_{1}}\left(R_{b} A_{b}+R_{s} A_{s}\right)>N_{d}
$$

where $\mathrm{R}_{\mathrm{b}}, R_{s}$ are the resistance of concrete and reinforcement accordingly,

$\mathrm{A}_{\mathrm{b}}, A_{s}$ - cross-sectional areas of the pile and the reinforcement,

$N_{d}$ - axial load.

If the parameters $\mathrm{R}_{\mathrm{b}}, R_{s}, N_{d}$ are considered as normally distributed random variables with known probability characteristics - mathematical expectations $\mathrm{m}\left(\mathrm{N}_{\mathrm{d}}\right), \mathrm{m}\left(\mathrm{R}_{\mathrm{b}}\right), m\left(R_{s}\right)$ and the standard deviations $\sigma\left(\mathrm{R}_{\mathrm{b}}\right), \sigma\left(R_{s}\right), \sigma\left(N_{d}\right)$, the probability of failure-less operation of the pile $P$ is determined by the relation 


$$
\mathrm{P}(\mathrm{F}<0)=\frac{1}{2}[1+\Phi(-\mathrm{m}(\mathrm{F}) / \sigma(F)]
$$

where: $\Phi-$ the function of normal distribution (Laplace),

$$
\mathrm{F}=\mathrm{N}_{\mathrm{d}}-\left(R_{b} A_{b}+R_{s} A_{s}\right)
$$

In general, when dealing with such problems function $\mathrm{F}$ is non-linear and the reliability assessment is carried out by various methods (linearization, statistical tests, etc.). In this example the function of random parameters $\mathrm{F}$ is linear of $R_{b}, R_{s}, N_{d}$ and has a normal distribution and its characteristics are determined in accordance with the rules laid down in the guidelines on probability theory for linear functions of normally distributed variables:

$$
\begin{gathered}
m(F)=m N_{\mathrm{d}}-\left[m\left(R_{b} A_{b}\right)+m\left(R_{s} A_{s}\right)\right], \\
\sigma(F)=\sqrt{\sigma^{2}\left(N_{d}\right)+\sigma^{2}\left(A_{b} R_{b}\right)+\sigma^{2}\left(R_{s} A_{s}\right)}
\end{gathered}
$$

By setting different values of the mathematical expectations of axial load $\mathrm{m}\left(\mathrm{N}_{\mathrm{d}}\right)$ we can obtain the probability of failure - free operation of the pile by material strength criterion.

It is known, however, that the correct use of probabilistic methods is associated with the presence of sufficiently complete statistical information on the basic random variables included in the mathematical models of limit states and loads. The lack of sufficient initial statistical information is the main reason of the emergence of the need to look for other (non-probabilistic) methods for uncertainties account. Since the 60 s of the last century the various theories for the formal description of uncertainties began to develop intensively. In particular, the possibility theory developed by American mathematician Zadeh [12] and its further development in Dubois and Prada work [7, 13] were fairly widespread.

\section{The result of its application is the interval estimate of reliability.}

Note that interval estimations can be obtained on the basis of a probabilistic approach as well, but the interval resulting from this analysis quite roughly estimates the required probability in most cases [8, 14].

Also a variety of combined techniques that allow the most complete account of the available information on the parameters are proposed. V.S. Utkin and N.S. Galaeva [25] proposed a method in which, depending on the availability of information, some variables are considered as random (in terms of probability theory) and others - as fuzzy ones (in terms of possibilities theory). For example, if $S$ is a fuzzy variable and $R$ is a random variable changing according to the normal distribution with the density function

$$
\rho_{R}(x)=\frac{1}{\sqrt{2 \pi} \sigma_{R}} \exp \left[-\frac{\left(x-m_{R}\right)^{2}}{2 \sigma_{R}^{2}}\right],
$$

then the expressions for the lower $\underline{P}$ and upper $\bar{P}$ boundaries of the reliability interval look like

$$
\begin{gathered}
\underline{P}=\int_{a_{S}}^{\infty} \frac{1}{\sqrt{2 \pi} \sigma_{R}} \exp \left[-\frac{\left(x-m_{R}\right)^{2}}{2 \sigma_{R}^{2}}\right]\left\{1-\exp \left[-\frac{\left(x-a_{S}\right)^{2}}{b_{S}^{2}}\right]\right\} d x, \text { with } \underline{P}_{S}(x)=0 \text { at } x \leq a_{S} ; \\
\bar{P}=\int_{0}^{a_{S}} \frac{1}{\sqrt{2 \pi} \sigma_{R}} \exp \left[-\frac{\left(x-m_{R}\right)^{2}}{2 \sigma_{R}^{2}}\right]\left\{\exp \left[-\frac{\left(x-a_{S}\right)^{2}}{b_{S}^{2}}\right]\right\} d x+\int_{a_{S}}^{\infty} \frac{1}{\sqrt{2 \pi} \sigma_{R}} \exp \left[-\frac{\left(x-m_{R}\right)^{2}}{2 \sigma_{R}^{2}}\right] d x,
\end{gathered}
$$

where $a_{S}$ - an average value and $b_{S}$ - a fuzziness factor are the parameters of fuzzy value $S$.

\section{Results and Discussion}

The estimations of the probability of failure-free operation of a pile based on the strength condition and made by the probabilistic and combined methods are discussed below. When using the combined 
method the pile bearing capacity was considered a random variable, the load - a fuzzy variable. The comparison of the results of two approaches is given in Table 1.

The evaluation of piles reliability with regard to the specific construction site does not introduce any fundamental changes in the technique and procedure of calculation under review.

As the initial data we will use the data of the example given in [4]:

the pile length $-12 \mathrm{~m}$

the cross section is a square which side is $0.35 \mathrm{~m}$

concrete class (options) - B10, B15, B20

reinforcement class $-\mathrm{A} 1$

cross sectional area, $\mathrm{m}^{2}-0.1225$

axial load variants (mean values), $\mathrm{kPa}-500-1500$

reinforcement cross-sectional area $\mathrm{m}^{2}-8.042 * 10^{-4}$.

The calculation results are shown in Figures 1 and 2 in the form of dependences of probability of ensuring pile strength on the axial load average value (mathematical expectation) for the three types of concrete. The comparison of the results of probabilistic and combined approaches is given in Table 1.

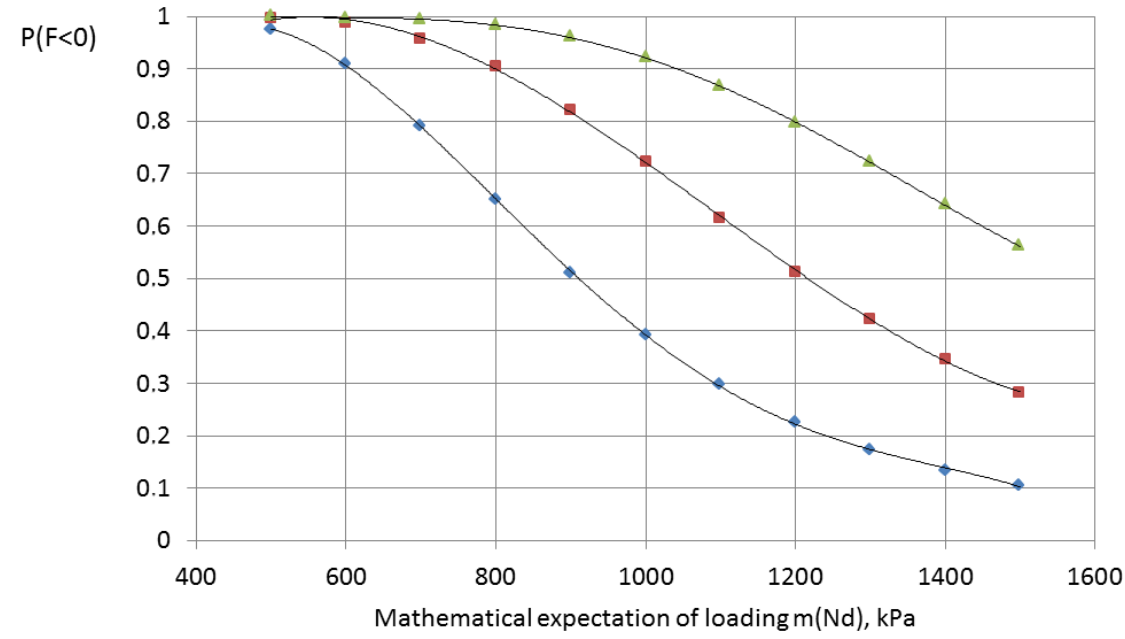

- Concrete class B10 $\quad$ Concrete classB15 $\quad$ Concrete class B20

Figure 1. The probability of ensuring the strength of the pile by the material strength criteria (reinforced concrete). Reinforcement class A1, the number of reinforcing bars 4

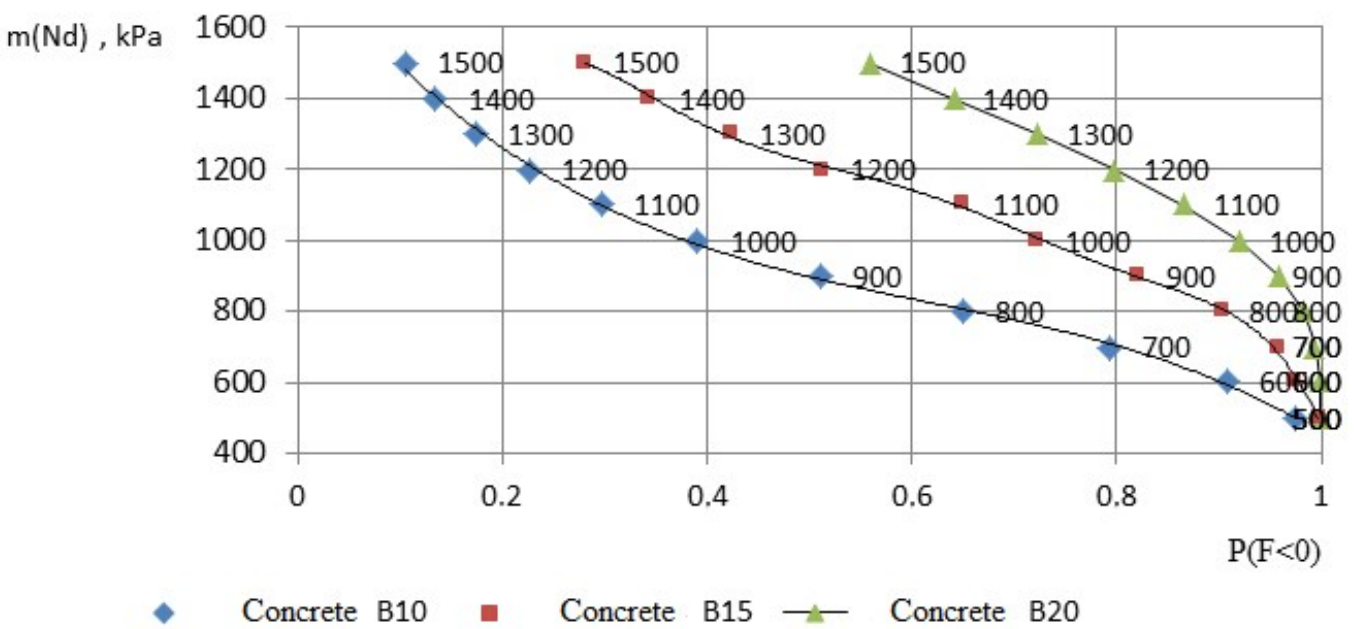

Figure 2. A pile strength probability as a function of an average value of axial loading Ivanova T.V., Albert I.U., Kaufman B.D., Shulman S.G. The load-bearing capacity of hanging piles by the strength 
Table 1. Probabilistic and combined estimations of failure-free pile operation according to strength criterion

\begin{tabular}{|c|c|c|c|c|c|c|}
\hline \multirow{2}{*}{$N_{d}, \mathbf{k P a}$} & \multicolumn{2}{|c|}{ Concrete B 10 } & \multicolumn{2}{c|}{ Concrete B 15 } & \multicolumn{2}{c|}{ Concrete B 20 } \\
\cline { 2 - 7 } & Prob. & Comb. & Prob. & Comb. & Prob. & Comb. \\
\hline 500 & 0.971 & $0.909 \div 1$ & 0.997 & $0.990 \div 1$ & 1 & $0.999 \div 1$ \\
\hline 600 & 0.901 & $0.720 \div 0.998$ & 0.987 & $0.955 \div 1$ & 0.998 & $0.994 \div 1$ \\
\hline 800 & 0.648 & $0.226 \div 0.970$ & 0.903 & $0.718 \div 0.997$ & 0.981 & $0.943 \div 1$ \\
\hline 1000 & 0.390 & $0.025 \div 0.853$ & 0.720 & $0.340 \div 0.980$ & 0.918 & $0.769 \div 0.997$ \\
\hline 1200 & 0.230 & $0.0 \div 0.644$ & 0.510 & $0.094 \div 0.922$ & 0.794 & $0.486 \div 0.988$ \\
\hline 1400 & 0.140 & $0.0 \div 0.442$ & 0.340 & $0.015 \div 0.804$ & 0.641 & $0.228 \div 0.962$ \\
\hline
\end{tabular}

The probability of ensuring required load-bearing capacity of a friction pile. groups:

It is known that the piles are classified on the basis of interaction with the soil environment into two

- pile-pillars that rely on rocky ground, and perceive the external axial load due to front resistance of the rock;

- friction piles - resistance consists of two components:

a) resistance forces arising due to the friction between the outer surface of the pile and the soil environment and

b) front resistance force due to the interaction between the lower end of the pile and the soil environment [9].The values of coefficients $R, f_{i}$ as the functions of the depth of a pile penetration, soil types and some physicomechanical characteristics are presented in the same tables and in graphs in Figures 3, 4 .

The method of estimation of reliability by the ground in a deterministic setting is based on the inequality:

$$
F=N_{d}-\frac{1}{k_{1}}\left(R^{*} A+u \cdot\left(\sum_{i} h_{i} f_{i}\right)<0,\right.
$$

where $F$ - reliability function,

$N_{d}$ - the axial load on the pile,

$R$ - front resistance coefficient,

$A$ - cross sectional area of the pile,

$u$ - the cross-sectional perimeter,

$h_{1}-$ the depth of the i-th layer,

$f_{i}-$ lateral resistance coefficient of the $\mathrm{i}$-th soil layer,

$k_{1}$ - safety factor.

The procedure for quantitative assessment of bearing capacity by the ground is carried out in the same sequence as in the previous example. Function $\mathrm{F}$ which determines the bearing capacity is linear regarding random parameters $N_{d}, R, f_{i}$. Assuming that all the random variables are normally distributed with known probability characteristics (mathematical expectations and dispersions) the expressions for them can be written as follows:

$$
\begin{gathered}
m(F)=m\left(N_{d}\right)-\left[\left(m\left(R^{*} A\right)+u_{1} h_{1} m\left(f_{1}\right)\right]\right. \\
\left(\sigma_{F}^{2}\right)=\sigma_{N_{d}}^{2}+A^{2} \cdot\left(\sigma_{R}^{2}\right)+(u h)^{2} \cdot \sigma_{f}^{2}+2 \cdot r_{A f} \cdot u h \cdot \sigma_{A} \cdot \sigma_{f},
\end{gathered}
$$


where $\sigma_{N_{d}}, \sigma_{R}, \sigma_{f}$ - standards for random variables, $r_{R f}$ - correlation coefficient for random variables $R, f$.

To estimate the degree of relation between random variables $R, f$ in Figure 5 there is a dependence $f(R)$.You can see from the graph that the coupling equation with a sufficient degree of accuracy can be approximated by a linear dependence; therefore, a normalized correlation coefficient may be set equal to one.

To simplify the calculation the soil foundation is assumed to be homogeneous: $i=1$; in the case of inhomogeneous foundation the sum of terms of the form $u \cdot h_{i} \cdot f_{i}$ should be calculated.

The calculation results are shown in Figure 6, which shows two dependencies: the probability of ensuring the bearing capacity by the pile material and by the foundation soil.

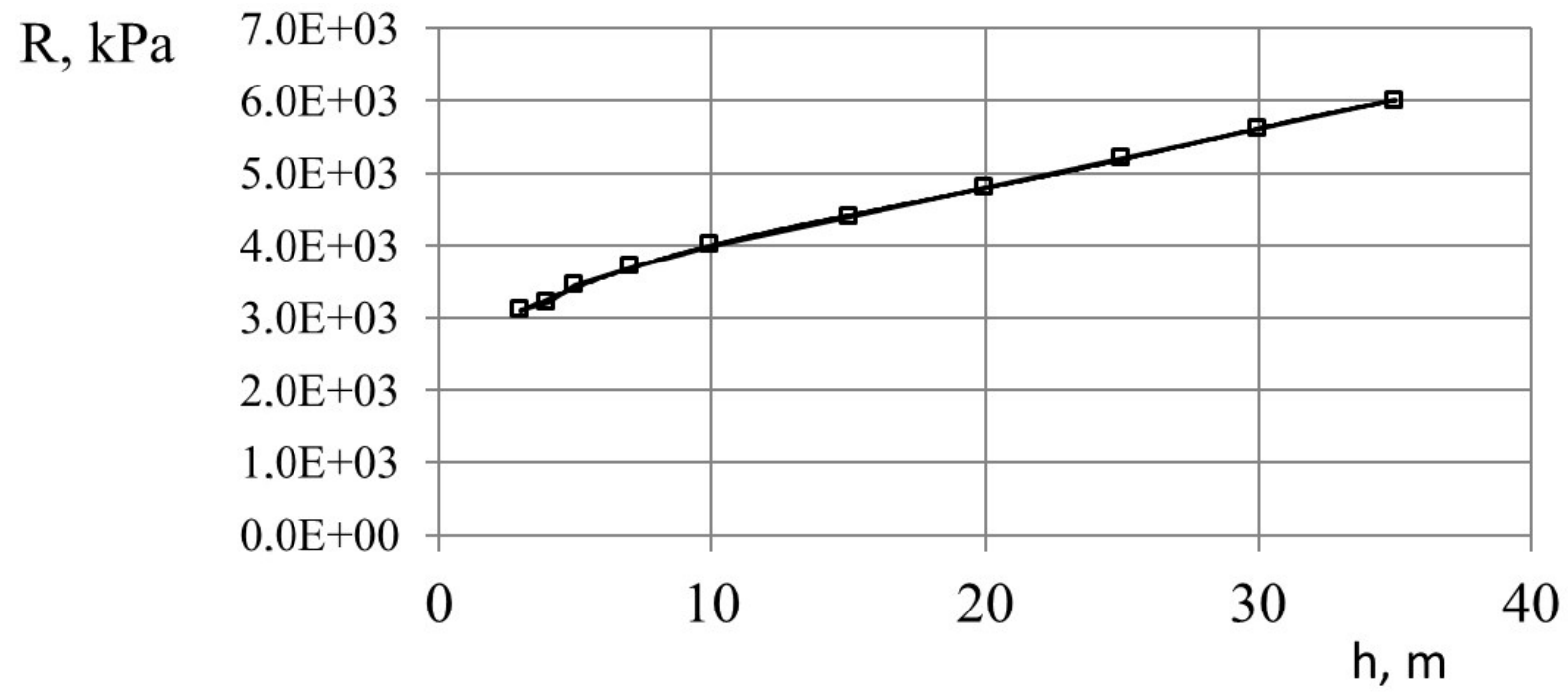

Figure 3. The dependence of the front resistance coefficient of the immersion depth of the pile

$\mathrm{f}, \mathrm{kPa}$

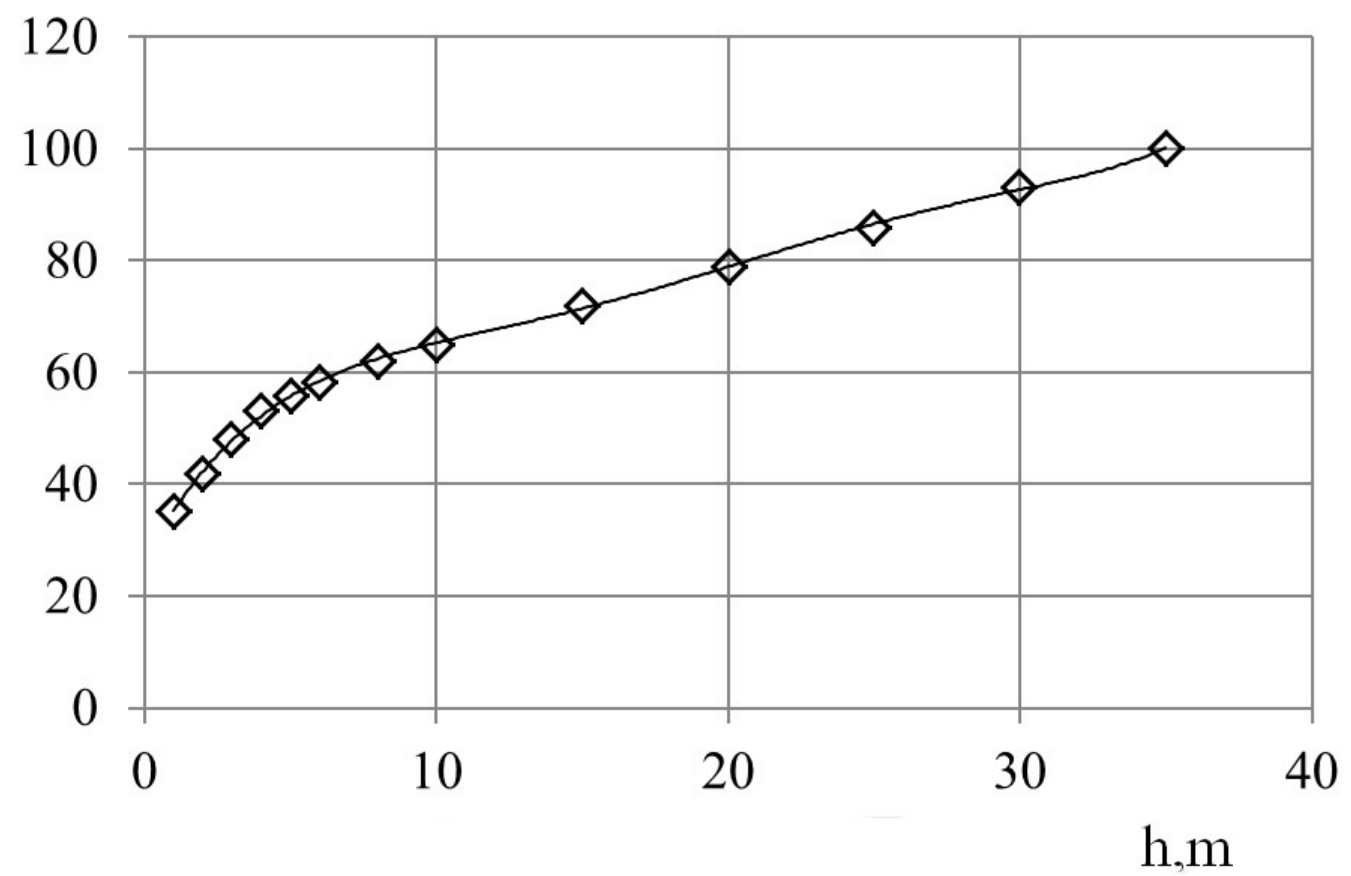

Figure 4. The dependence of the lateral resistance coefficient of the immersion depth of the pile

Ivanova T.V., Albert I.U., Kaufman B.D., Shulman S.G. The load-bearing capacity of hanging piles by the strength 


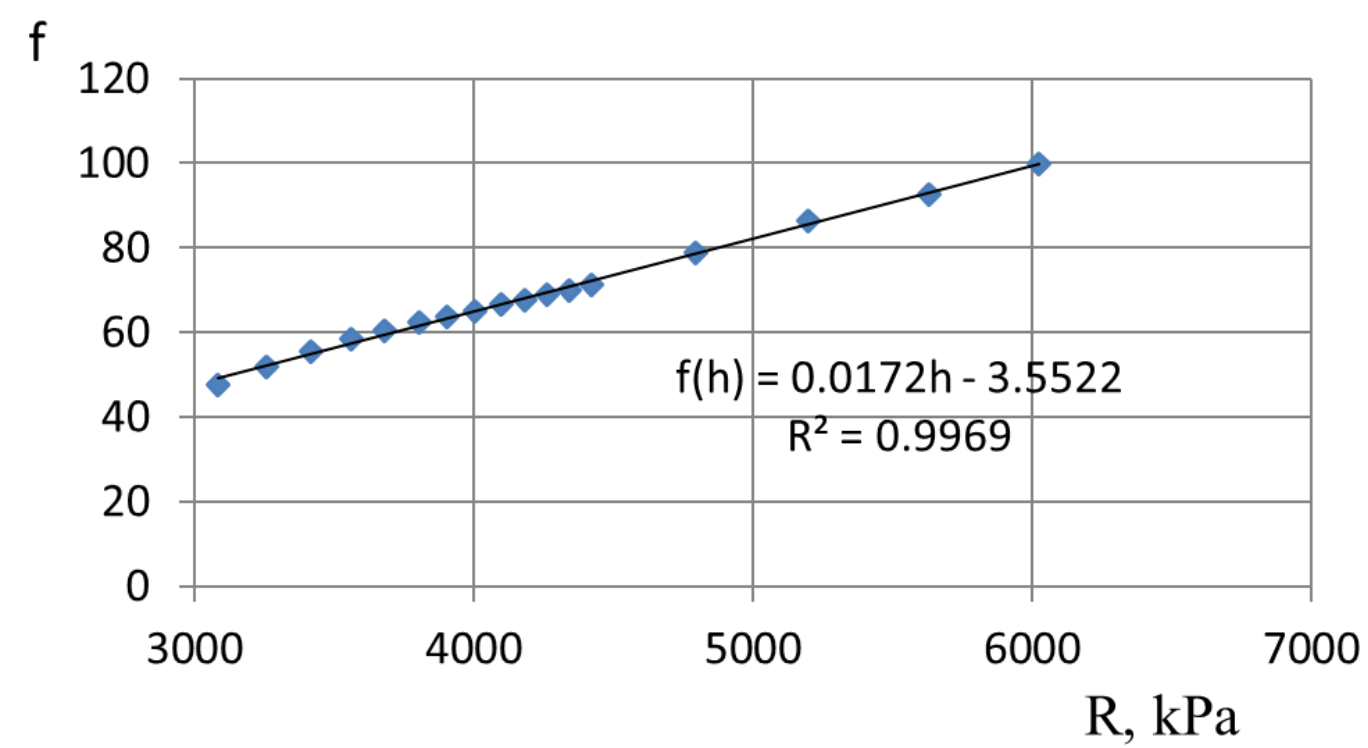

Figure 5. The relation between random variables

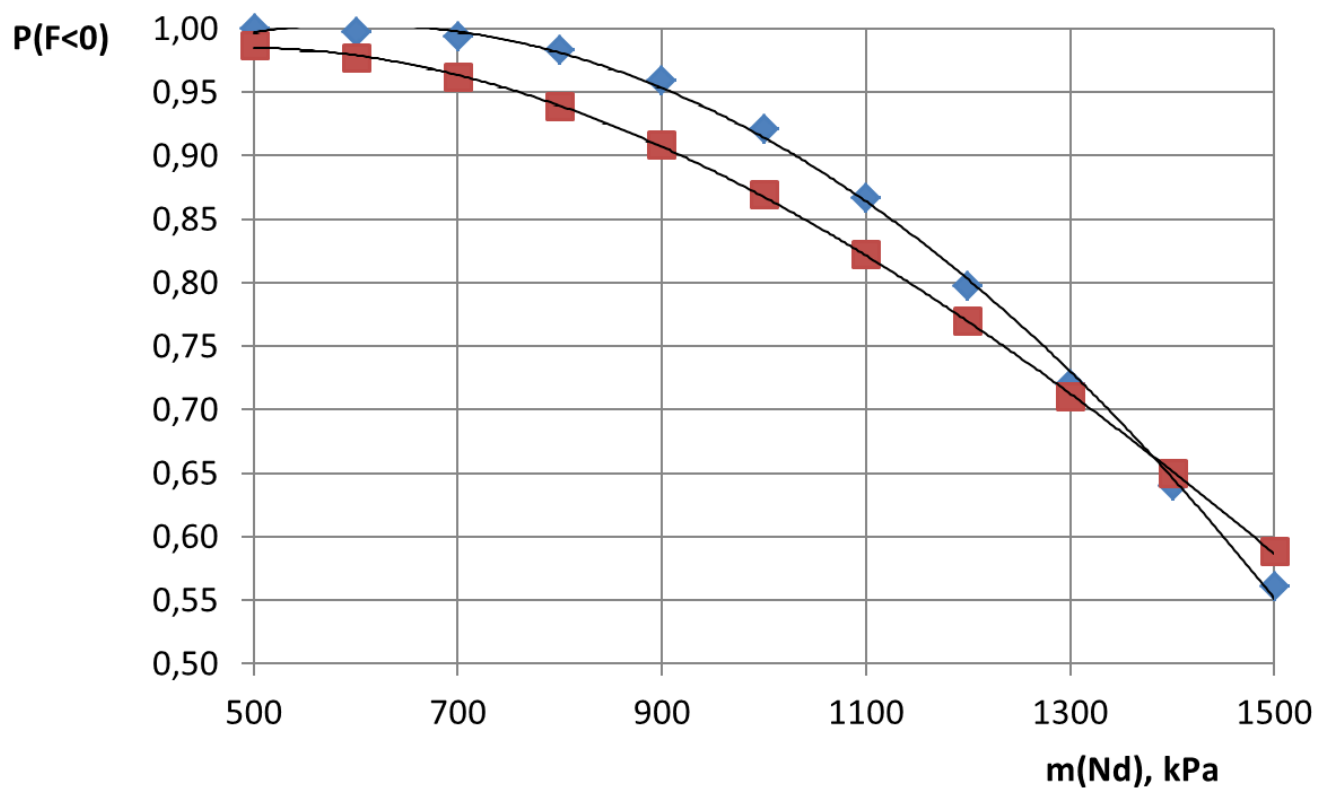

$\checkmark$ Concrete B20 Soil

Figure 6. The probabilities of ensuring a friction pile bearing capacity by the ground and by the pile material

The graph in Figure 6 shows the dependences of the probability of ensuring a given level of reliability by pile material strength and by soil material. The graph shows that with the load increase the probability of reliable operation of the pile decreases both by the soil strength criterion and by the pile material strength criterion.

Table 2 shows the results of estimation by the foundation soil for a failure - free pile operation in two cases - in the first case loading and soil characteristics are represented by random variables and point probability estimation is given and in the second case loading is a fuzzy variable, and ground characteristics are random ones, i.e. a combined method giving the interval estimation is used. In all cases, the probabilistic estimations lie within the intervals. 
Table 2. Probabilistic and combined estimations of failure-free pile operation based on the foundation soil

\begin{tabular}{|c|c|c|}
\hline$N_{d}, \mathbf{k P a}$ & $\boldsymbol{P}$ Prob & $\boldsymbol{P}$ Comb. \\
\hline 500 & 0.987 & $0.975 \div 0.996$ \\
\hline 600 & 0.977 & $0.953 \div 0.993$ \\
\hline 800 & 0.938 & $0.871 \div 0.985$ \\
\hline 1000 & 0.869 & $0.726 \div 0.970$ \\
\hline 1200 & 0.770 & $0.538 \div 0.944$ \\
\hline 1400 & 0.65 & $0.348 \div 0.905$ \\
\hline
\end{tabular}

The comparison of pile load-bearing capacity calculations by the pile material and foundation soil allows for the following conclusion:

- from the two variants of load-bearing capacity estimations the bearing capacity by the soil is less favorable (with the exception of the medium axial loads of more than $1,400 \mathrm{kPa}$ )

- the final load-bearing capacity estimation at adopted initial data is taken minimal.

The proposed method allows a quantitative assessment of the load-bearing capacity and reliability of a pile with incomplete information about the characteristics of the soil parameters and loads, as well as the considerable variation in the original data values. In the works of other authors such a possibility was not available until now.

The deterministic approach used by other authors' results in a qualitative assessment only. The correct application of probabilistic methods giving a point result cannot always be realized due to lack of the initial information. In this situation the authors use the combined method in which the parameters of the problem are presented as fuzzy values $[7,12]$ and which gives a reliable interval assessment (Table 2).

\section{Conclusion}

Thus, in this article the technique of quantitative assessment of piles reliability under incomplete initial information about the parameters of mathematical models is presented.

Presented in the article methods for a quantitative assessment of single piles reliability can be used for more complex computational models, including multielement pile foundations and more complex models of soil foundations.

These methods have not been applied to piles reliability research so far and the article presented is a pioneering one and has no analogues known to the authors.

\section{References}

1. Gotman A.L. Raschet kombinirovannykh svaynykh fundamentov na deystviye gorizontalnoy nagruzki i izgibayushchego momenta [Calculation of combined pile foundations exposed to horizontal load and bending moment]. Osnovaniya, Fundamenty i Mekhanika Gruntov. 2015. No. 4. Pp. 23-27. (rus)

2. Glagovskiy V.B. O raschetnoy otsenke nesushchey sposobnosti trubchatykh svay na arkticheskom shelfe [About a calculated estimation of bearing capacity of pipe piles on the Arctic shelf]. Izvestiya VNIIG im.B.Ye. Vedeneyeva. 1999. Vol. 234. Pp. 61-66. (rus)

3. Glagovsky V.B., Sosnina S.A. Raschet deformazii svaiobolochki pod deystviem gorizontalnoy nagruski । momenta.[Calculation of the deformation of a shell pile under the action of the horizontal load and bending moment]. Proceeding of the VNIIG. 2004. Vol. 243. Pp. 7782. (rus)

4. Glagovsky V.B., Prokopovich V.C., Sozinova T.A., Sosnina M.A. Nesuchaya sposobnost zasasuvaemux svay. [The bearing capacity of suction piles]. Proceeding of the VNIIG. 2001. Vol. 239. Pp. 128-135. (rus)

5. Golovchenko V.B. Kombinirovanie modeley neopredelennosti [Combining uncertainty models]. Novosibirsk: Nauka, 2002. 190 p. (rus)

Ivanova T.V., Albert I.U., Kaufman B.D., Shulman S.G. The load-bearing capacity of hanging piles by the strength criterion of a pile or soil material. Magazine of Civil Engineering. 2016. No. 7. Pp. 3-12. doi: 10.5862/MCE.67.1

\section{Литература}

1. Готман А.Л. Расчет комбинированных свайных фундаментов на действие горизонтальной нагрузки и изгибающего момента // Основания, фундаменты и механика грунтов. 2015. № 4. С. 23-27.

2. Глаговский В.Б. О расчетной оценке несущей Известия ВНИИГ им.Б.Е. Веденеева. 1999. Т. 234. C. 61-66.

3. Глаговский В.Б., Соснина С.А. Расчет деформации сваи-оболочки под действием горизонтальной нагрузки и момента // Известия ВНИИГ им.Б.Е. Веденеева. 2004. T. 243. С. $77-82$.

4. Глаговский В.Б., Прокопович В.С., Созинова Т.А., Соснина М.А. Несущая способность засасываемых свай // Известия ВНИИГ им.Б.Е. Веденеева. 2001. T. 239. С. $128-135$.

5. Головченко В.Б. Комбинирование моделей неопределенности. Новосибирск: Наука, 2002. 190 с.

6. Гуров С.В., Уткин Л.В. Надёжность систем при неполной информации. СПб: Любавич, 1999. 160 с.

7. Дюбуа Д., Прад А. Теория возможностей. Приложение к представлению знаний в информатике. М.: Радио и способности трубчатых свай на арктическом шельфе // 
6. Gurov S.V., Utkin L.V. Nadegnost system pri hepolnoy informazii [Reliability of systems with the incomplete information]. Saint Petersburg: Lubavitch, 1999. 160 p. (rus)

7. Dubois D., Prade H. Teoriya vozmoznostey. Prilozenie $k$ predstavleniy znaniy $v$ informatike [Possibility theory. An application to representation of knowledge in informatics]. Moscow: Radio i svjaz. 1990. 228 p. (rus)

8. Kaufman B.D., Schulman S.G. Dinamika system "sooruzenie-osnovanie" pri nepolnoy isxodnoy informazii (uchet sluchaynux i neopredelennyx faktorov) [Dynamics of "structure-foundation" systems with incomplete initial information (random and uncertain factors accounting)]. Saint Petersburg, 2015. 418 p. (rus)

9. Mangushev R.A., Gotman A.L., Znamenskij V.V., Ponomarev A.B. Svai $i$ svaynie fundamente. Konstruirovanie, proektirovanie, texnologii [Piles and pile foundations. Design, engineering, technol-ogy]. Moscow: ASV, 2015. 314 p. (rus)

10. Dempster A.P. Upper and lower probabilities induced by a multivalued mapping. Annales of Matematical Statistics. 1967. Vol. 38. Pp. 325-339.

11. Shafer G.A. Mathematical Theory of Evidence. Princeton University Press. New Jork, 1976. 314 p.

12. Zadeh L.A. Fuzzy sets as a basis for a theory of possibility. Fuzzy Sets and Systems. 1978. Vol. 1. Pp. 3-28.

13. Cai K.Y. Introduction to Fuzzy Reliability. Kluwer Academic Publishers. Boston, 1996. 311 p.

14. Shokin Yu.A. Intervalnyy analiz [Interval analysis]. Novosibirsk: Nauka, 1981. 112 p. (rus)

15. Bond A.J., Jurdine R.J. Effect installing displacement pilesin a high OCR clay. Geitechnique. 1991. No. 3(41). Pp. 341-393

16. Prakash S., Sharma H.D. Pile foundation in Engineering Practice. John Wiley and Sons. New York, 1989. 784 p.

17. Reeese L.C., Cox W.R., Koop F.D. Analysis of lateral loaded piles in sand. Proceedings of IV Annual Technology Conference. 1974. Pp. 473-483.

18. Paik K.-H., Lee S.R. Behavior of soil plugs in open ended model piles driven into sands. Marine Georesources and Geotechnology. 1993. No. 4(11). Pp. 353-373.

19. Kaufman B.D. Evaluation of design reliability of apron-slab stabilization based on incomplete parameter information on design models. Power Technology and Engineering. 2013. No. 4(47). Pp. 244-248.

20. Kaufman B.D., Andrianova E.A. Probabilistic and possibilistic estimates of generating-set vibrations at HPP due to water pulsation in toe basin. Power Technology and Engineering. 2014. No. 4(48). Pp. 264-267.

21. Kaufman B.D., Andrianova E.A. Otzenka dempfiruyzego vliyaniy osnovaniy na kolebaniy sooruzeniy (determinirovanniy, veroyatnostniy I vozmoznostny podxod) [Estimate dempfing in-fluence of base on vibration of buiding]. Magazine of Civil Engineering. 2012. No. 9(35). Pp. 85-96. (rus)

22. Usmanov R., Mrdak I., Vatin N., Murgul V. Reinforced soil beds on weak soils. Applied Mechanics and Materials. 2014. Vols. 633-634. Pp. 932-935.

23. Utkin V.S. Raschet nadezhnosti gruntovykh osnovaniy fundamentov zdaniy i sooruzheniy po kriteriyu deformatsii pri ogranichennoy informatsii o nagruzkakh i gruntakh [Reliability calculation of soil basements of buildings and structures foundations by deformation criterion with limited information about loads and soils]. Magazine of Civil Engineering. 2016. No. 1(61). Pp. 4-13. (rus)

24. Utkin V.S., Utkin L.V. Novyye metody raschetov nadezhnosti stroitelnykh konstruktsiy [New methods of constructions reliability calculations]. Vologda: VoGTU, 2011. 98 p. (rus)

25. Galaeva N.L., Utkin V.S. Opredelenie nadeznosti elementov konstruktsiy po kriteriy prochnosti kominirovannym
Связь, 1990. 228 с.

8. Кауфман Б.Д., Шульман С.Г. Динамика систем "сооружение-основание» при неполной исходной информации (учет случайных и неопределенных факторов). СПб.: ОАО «ВНИИГ им.Б.Е. Веденеева», 2015. $418 \mathrm{C}$

9. Мангушев Р.А., Готман А.Л., Знаменский В.В., Пономарев А.Б. Сваи и свайные фундаменты. Конструирование, проектирование, технологии. М.: ACB, 2015. $314 \mathrm{c}$.

10. Dempster A.P. Upper and lower probabilities induced by a multivalued mapping // Annales of Matematical Statistics. 1967. Vol. 38. Pp. 325-339.

11. Shafer G.A. Mathematical Theory of Evidence. New Jork: Princeton University Press, 1976. 314 p.

12. Zadeh L.A. Fuzzy sets as a basis for a theory of possibility // Fuzzy Sets and Systems. 1978. Vol. 1. Pp. 3-28.

13. Cai K.Y. Introduction to Fuzzy Reliability. Kluwer Academic Publishers. Boston, 1996. $311 \mathrm{p}$.

14. Шокин Ю.А. Интервальный анализ. Новосибирск: Наука, 1981. 112 с.

15. Bond A.J., Jurdine R.J. Effect installing displacement pilesin a high OCR clay. Geitechnique. 1991. № 3 (41). Pp. 341-393.

16. Prakash S., Sharma H.D. Pile foundation in Engineering Practice, John Wiley and Sons, New York. 784 p.

17. Reeese L.C., Cox W.R., Koop F.D. Analysis of lateral loaded piles in sand // Proceedings of IV Annual Technology Conference. 1974. Pp. 473-483.

18. Paik K.-H., Lee S.R. Behavior of soil plugs in open ended model piles driven into sands // Marine Georesources and Geotechnology. 1993. № 4(11). Pp. 353-373.

19. Kaufman B.D. Evaluation of design reliability of apron-slab stabilization based on incomplete parameter information on design models // Power Technology and Engineering. 2013. № 4(47). Pp. 244-248.

20. Kaufman B.D., Andrianova E.A. Probabilistic and possibilistic estimates of generating-set vibrations at HPP due to water pulsation in toe basin // Power Technology and Engineering. 2014. № 4(48). Pp. 264-267.

21. Кауфмман Б.Д., Андрианова Е.А., Шульман С.Г. Оценка демпфирующего влияния основания на колебания сооружения (детерминированный, вероятностный и возможностный подход) // Инженерно-строительный журнал. 2012. № 9(35). С. 85-96.

22. Usmanov, R., Mrdak, I., Vatin, N., Murgul, V. Reinforced soil beds on weak soils // Applied Mechanics and Materials. 2014. Vols. 633-634. Pp. 932-935.

23. Уткин В.С. Расчет надежности грунтовых оснований фундаментов зданий и сооружений по критерию деформации при ограниченной информации о нагрузках и грунтах // Инженерно-строительный журнал. 2016. № 1(61). С. 4-13.

24. Уткин В.С., Уткин Л.В. Новые методы расчетов надежности строительных конструкций. Вологда: ВоГТУ, 2011. $98 \mathrm{c}$.

25. Галаева Н.Л., Уткин В.С. Определение надежности элементов конструкций по критерию прочности комбинированным методом // Строительная механика и расчет сооружений. 2008. № 3(218). С. 42-46.

26. Маций С. И., Рябухин А. К., Безуглова Е. В., Коломиец М. С. Рациональное проектирования свайно-анкерных конструкций // Труды Кубанского государственного аграрного университета. 2013. № 2(41). С. 160-163.

27. СП 24.13330.2011 Свайные фундаменты.

28. Рыжков И.Б., Исаев О.Н. Статическое зондирование грунтов. М: Издательство Ассоциации строительных вузов, 2010. 496 с.

29. Bonic Z., Curcc G.T., Trivunic M., Davidovic N., Vatin N.

Иванова Т.В., Альберт И.У., Кауфман Б.Д., Шульман С.Г. Несущая способность висячих свай по критерию прочности материала сваи или грунта // Инженерно-строительный журнал. 2016. № 7(67). С. 3-12. 
metodom [Determination of structural elements reliability according to the strength criterion by combined method]. Structural Mechanics and Analysis of Constructions. 2008. No. 3(218). Pp. 42-46. (rus)

26. Matsiy S. I., Ryabukhin A. K., Bezuglova Ye. V., Kolomiyets M. S. Ratsionalnoye proyektirovaniya svayno-ankernykh konstruktsiy [Rational design of pile-anchor structures]. Trudy Kubanskogo gosudarstvennogo agrarnogo universiteta. 2013. No. 2(41). Pp. 160-163. (rus)

27. $S P$ 24.13330.2011. Svajnye fundamenty [Building Regulation SP 24.13330.2011. Pile foundations]. (rus)

28. Ryzhkov I.B., Isaev O.N. Staticheskoe zondirovanie gruntov [Static ground probing]. Moscow: IASV, 2010. 496 p. (rus)

29. Bonic Z., Curcc G.T., Trivunic M., Davidovic N., Vatin N. Some methods of protection of concrete and reinforcment of reinforced-concrete foundations exposed to environmental impacts. Procedia Engineering. 2015. No. 1(117). Pp. 424435.

Tatiana Ivanova,

+7(812)4939363; IvanovaTV@vniig.ru

Iulya Albert,

+7(950)0224341; Albert/U@vniig.ru

Boris Kaufman,

+7(963)3455718; KaufmanBD@vniig.ru

Sergey Shulman,

+7(911)7522161; ShulmanSG@vniig.ru
Some methods of protection of concrete and reinforcment of reinforced-concrete foundations exposed to environmental impacts // Procedia Engineering. 2015. № 1(117). Pp. 424-435.
Татьяна Викторовна Иванова,

+7(812)4939363; эл. почma: IvanovaTV@vniig.ru

Июля Ушерович Альберт,

+7(950)0224341; эл. почma: Albert/U@vniig.ru

Борис Давидович Кауфман, +7(963)3455718; эл. почma: KaufmanBD@vniig.ru

Сергей Георгиевич Шульман,

+7(911)7522161; эл. почma: ShulmanSG@vniig.ru

(C) Ivanova T.V., Albert I.U., Kaufman B.D., Shulman S.G., 2016

Ivanova T.V., Albert I.U., Kaufman B.D., Shulman S.G. The load-bearing capacity of hanging piles by the strength 